\title{
Effect of Legal Sanction for Shareholders' Expropriation on the Corporate Valuation
}

\author{
Zhigang Yao*, Yu Li \\ School of Economics and Management, Southwest Jiaotong University, Chengdu, China \\ Email: *meidexiang1101@126.com
}

Received 27 May 2016; accepted 23 July 2016; published 26 July 2016

Copyright (C) 2016 by authors and Scientific Research Publishing Inc.

This work is licensed under the Creative Commons Attribution International License (CC BY). http://creativecommons.org/licenses/by/4.0/

(c) (i) Open Access

\begin{abstract}
The purpose of this paper is to study whether the legal sanction by relevant departments for the majority shareholders' expropriation affects the valuation of the firms' or other shareholders' interests. This study takes the legal sanction by relevant departments for the majority shareholders' expropriation as external legal environment change events, so whether the return of the listed company shows significant difference during the window before and after the listed company has been sanctioned by the relevant departments for the majority shareholders' expropriation will be the judgment whether the sanction has any obvious effect on the listed company and the stock market. The study demonstrates that almost all empirical results show that the positive and negative effects don't pass the significance test, illustrating that the legal sanction system just has limited effect on the corporate governance of the listed company.
\end{abstract}

\section{Keywords}

Shareholder's Expropriation, Event Study, Window, Return

\section{Introduction}

During the post-split-share structure period, the traditional benefit expropriation may incur more risks, therefore the controlling shareholders' expropriation and other torts have been effectively curbed, but they haven't been completely eradicated. Controlling shareholders may avoid the regulation and supervision to transfer the listed company's interests to themselves in more subtle and hidden way. For example, in 2012 Zhendong Group expropriated a total of 36 million and 470 thousand Yuan from the listed company Zhendong Pharmaceutical through a series of hidden related transactions, and therefore was publicly censured by Shenzhen Stock Exchange. Since the year of 2011, Zhendong Group has pledged the shares of Zhendong Pharmaceutical to obtain

*Corresponding author. 
loans from several banks. The total number of equity pledge is already up to 31.91 million shares, and the financed amount exceeds 200 million Yuan calculated at the lowest stock price. Meanwhile, by illegally paying excessive construction cost, Zhendong Pharmaceutical transferred large amounts of money to Zhendong Group and its subsidiaries; therefore a large amount of funds of the listed company had been occupied by its controlling shareholder.

As an emerging market economy country, China has an imperfect legal system of investor protection with a not-high degree of marketization, relative concentration of listed company's equity capital, majority shareholders holding and a low level of internal governance as a whole. Therefore the majority shareholders' expropriation of minority shareholders and the behavior of tunneling the listed company by majority shareholders are prevail. From 2005 to 2007, China completed its split-share structure reform, and realized the all-round circulation of stock in the market, resuming its original attribute of the shares of listed companies-the same share with the same price, same right and same profit, thus laying the common interests foundation of the listed company's corporate governance and consolidating the cornerstone of capital market. With the completion of the split-share structure reform, what will stimulate majority shareholders to actively promote asset injection, the overall listing of the company and other supporting actions? Whether majority shareholders still expropriate the listed company and its minority shareholders by manipulating its control? Whether the expropriation of the listed company will be reduced for the convergence of the interests between majority and minority shareholders? Whether other shareholders exert more constraint on majority shareholders? Whether minority shareholders may abnormally expropriate the listed company or majority shareholders? Whether the split-share structure reform will improve the corporate governance? Whether the improvement of the corporate governance and institutional environment will help contain the controlling shareholders' expropriation behavior? All these issues are worthy of attention and consideration, and this paper attempts to unveil them gradually.

In consideration of the aforesaid, this paper will begins with the expropriation of minority shareholders by majority shareholders, takes the sanction by the relevant departments for the majority shareholders' expropriation as external legal environment change events, so whether the return of the listed company shows significant difference during the window before and after the listed company has been sanctioned by the relevant departments for the majority shareholders' expropriation will be the judgment whether the sanction has any obvious effect on the listed company and the stock market. The study demonstrates that almost all empirical results show that the positive and negative effects don't pass the significance test, illustrating that the legal sanction system just has limited effects on the corporate governance of the listed company. According to the current study, during the post-split-share structure period, the majority shareholders' expropriation is a normal state of the company's ownership game, the optimization of the ownership structure can exogenously reduce the majority shareholders' expropriation of the listed company and minority shareholders, and the improvement of the corporate governance will endogenously reduce the expropriation significantly.

\section{Literature Review}

The study of LLS (1999) [1] tends to set the boundary of the equity concentration as the "exogenous boundary" of the majority shareholders' expropriation behavior. Within the boundary of equity structure determined by the exogenous legal environment, the expropriation of minority shareholders by majority shareholders is logically considered to be a "normal state". When they directly hold the post or appoint the management of the company, or when the legal protection of minority shareholders is not sufficient, the benefit expropriation and benefit siphoning are especially serious. The study of Claessens [2] demonstrates that the majority shareholders' expropriation often involves the exogenous legal environment, because the legal environment affects the control's private benefit. The legal environment in East Asian Countries generally is not as good as that in Western Countries and the protection of minority shareholders is not as good as that in Western Countries. Therefore, the private benefit for majority shareholders in East Asian Countries is much higher, which then determines a balanced ownership structure. This study shows that in many countries the basic problem plaguing listed companies is no longer the agency problem between shareholders and the management, but the one between internal controlling shareholders and outside investors, once again confirming that the game between the shareholders in a company is the normal "game” state in a company’s operation and management. Mara and Larry (2000) [3] make a study of the separation of ownership and control of 5323 companies in 13 European Countries. The empirical results show that majority shareholders enhance their controls of listed companies through the pyramid structure, the 
binary stock and cross holdings. Different companies in different countries may emphasize different ways, but overall the separation of corporate control and ownership is not significant.

On the whole, the majority shareholders' expropriation behavior is a "normal state", which is the "agency paradox" that the corporation must face in its corporate governance according to the information asymmetry theory. Facing the "normal state" of the majority shareholders' expropriation after the split-share structure reform in China, first, we should have a clear idea that the significant difference before and after the split-share structure reform, namely, there have different features between the pre- and post-split-share structure reform. Second, for the information asymmetry problem is still ubiquitous after the split-share structure reform, the study of the majority shareholders' expropriation from the perspective of corporate governance is of realistic and practical significance.

\section{Effect of Legal Environment on Majority Shareholders' Expropriation Mechanism}

\section{Analysis of Behavioral Theory}

1) Patterns of Behavior of Majority Shareholders' Expropriation of Minority Shareholders during Post-SplitStructure Reform

Scholars' representative study on the majority shareholders' expropriation mainly focuses on the ways and the consequences of the expropriation, providing a comparatively sufficient argument for the universality of the majority shareholders' expropriation. While in China, there is a watershed for the majority shareholders' expropriation before and after the split-share structure reform. Majority shareholders change from the heterogeneity-the mix of government entities and family businesses- to the homogeneous market entity, therefore, the study of the majority shareholders' expropriation after the split-share structure reform under the condition of the same share with same right is of practical significance, demonstrating the universality of the marketization process. Combining with the shareholders' expropriation and corporate governance, the study in fact aims to clarify the behavior equations of the so-called expropriation effect and tunneling effect, to analyze the motivation and purpose why majority shareholders expropriate minority shareholders, to explore the characteristics of the majority shareholders' normalized expropriation behavior and effective control measures in the mature market after the split-share structure reform.

With the realization of the same share with the same right, the state-owned shares, state-owned legal person shares and other shares are unleashed into the secondary market, and the shareholders' interests are directly reflected by the shares' market price. Based on market value, the majority shareholders' rights and interests are reflected as follows:

One, the share price. The corporate value is no longer the net assets pre-split-share structure reform, but the market value of the corporation. The shareholders' rights and interests are most directly reflected as equity value, among which, the basic composition is the dividend decided by dividend policy, but at the same time, the same share with the same right also means the shareholders' rights to participate in the management and the claim to the residue deriving from the ownership.

Two, benefits of control. Majority shareholders expropriate the listed company to maximize their own interests through a series of different ways, such as duty encroachment, affiliate transaction and insider trading. These actions not only expropriate the company, but also minority shareholders.

Three, capital gains. Comparing with minority shareholders, majority shareholders are usually "too big to fail" with their $1^{\text {st }}$-move advantage in capital gains. During the process of refinancing in the secondary market, transferring assets in funneling way, making dividend policy and manipulating surplus, majority shareholders can seek unjust profit and substantially expropriate minority shareholders by taking advantage in respect of funds, shareholding and information.

In fact, the post-split-share structure reform is just the beginning of the expropriation of minority shareholders by majority shareholders in diversified ways, and it becomes a common state for the homogeneous entities to tunnel the listed company and expropriate minority shareholders. Developing from the original heterogeneous entities to the homogeneous ones, majority shareholders behave in a more complex way. Based on the entities' behavior after the realization of the same share with the same right, and considering the conflict among majority shareholders, the management and minority shareholders, this paper attempts to formulate the behavior equation of conflicting entities, explore the normalized pattern of the majority shareholders' expropriation, and sort out 
the generation and choice law of the majority shareholders' normalized expropriation behavior, balancing between short-term expropriation and long-term expropriation and finding out the behavior logic to stimulate majority shareholders. The aim for majority shareholders to expropriate minority shareholders is to gain the private benefits of control, the amount of which will affect majority shareholders' total revenue. If they can get generous private benefits, majority shareholders will take measures to expropriate minority shareholders. While if the private benefits are not generous enough, majority shareholders may constrain their expropriation to some extent, and take supervisory measures to promote the long-term development of the listed company.

2) Analysis of Mechanism of Majority Shareholders’ Expropriation of Minority Shareholders

a) Analysis of Principal-Agent Relationship in Majority Shareholders’ Expropriation of Minority Shareholders

Berle and Means (1932) pioneered to put forward the issue of the separation of ownership and managerial authority in the modern company system, and on Berle and Means’ pioneering study, Harold Demsetz, Michael C. Jensen, William Meckling, Sanford J. Grossman, Oliver Hart and other scholars develop and build the "principal-agent theory" in corporate governance. The traditional agency theory mainly focuses on the management and the owner, and the difference of interest demands between them formed the game of the management and shareholders. Directly running the company and oriented by its own interests, the management tends to infringe on the rights and interests of shareholders in its agent behavior. According to the double principal-agent theory put forward by Feng Genfu (2004) [4], namely, in the joint-stock company with extreme or relative concentration of equity, there are in fact two kinds of principal-agent issues:

The 1st one is the principal-agent issue between controlling shareholders or majority shareholders and the management;

The 2nd one is the principal-agent issue between minority shareholders and their agents.

Specifically, because of their disadvantages in respect of funds, information, control and management, minority shareholders have to resort to the agents who are maybe majority shareholders or the management, thus forming the crossing agent or the secondary proxy mode. Investigating the majority shareholders' expropriation post-split-share structure reform, this paper takes the expropriation as a normal pattern, namely, it is inevitable for majority shareholders to expropriate minority shareholders. Based on the theory of benefit maximization and rational choice, majority shareholders will choose one kind of expropriations to maximize the utility accepted by them. The same as majority shareholders, minority shareholders also has the interest demands to run the company or affect the company's decision. Because of their disadvantages in respect of funds, information and the management tool, minority shareholders tend to entrust majority shareholders or controlling shareholders with the authority, but the abuse of the authority will lead to the expropriation of minority shareholders. For instance, by using their controls, majority shareholders tend to hollow out the listed company to seek their own benefits through the affiliate transaction, and the interests of minority shareholders have been encroached on by varying degrees.

From the perspective of motivation, minority shareholders always like to take a free ride, namely, they have the "inertia" to supervise the management. Whether their double disadvantages in respect of funds and information, or the high cost to monitor the agent, all lead to a dilemma that minority shareholders tend to, but finally fail to participate in the management of the company, losing the initiative and falling in a passive state in the principal-agent relationship for a long time. Under the passive state in the principal-agent relationship minority shareholders cannot have the initiative over controlling shareholders, majority shareholder and the management. Therefore, the majority shareholders' expropriation becomes a normal pattern in the process of the operation and management of the company. Difficult to participate in the management of the company, minority shareholders thus lose the choice toward the majority shareholders' expropriation, but can exert some kind of binding on the majority shareholders' expropriation to certain extent.

b) The Game Mechanism for Majority Shareholders’ Expropriation of Minority Shareholders

The above analysis shows that shareholders are naturally exclusive of each other because of the interest game among themselves. This paper attempts to construct a measurement index of rejection to measure the exclusiveness among shareholders, and apply the tort cost and the rejection among shareholders to measure the majority shareholders' expropriation of minority shareholders by comprehensively considering the "cost and utility" of the majority shareholders' torts. In its essence, the measurement index of rejection is to measure the degree of rejection that minority shareholders are expropriated by majority shareholders, and the most intuitive index is the opportunity cost and the number of the expropriated minority shareholders, namely, the quantitative rejection. In order to better illustrate the application of the opportunity cost of the expropriation can reduce the rejec- 
tion and improve the inclusion among shareholders, this paper, by referencing the trading possibility set model, figures out the opportunity cost of the majority shareholders' expropriation of minority shareholders to explain the relationship between the opportunity cost of the tort and the rejection among shareholders.

3) Theoretical Construction of the Boundary of Majority Shareholders' Expropriation

a) The Highest Expropriation Accepted by Minority Shareholders

Let's assume the set of the company's minority shareholders is $I$, and the equity capital of minority shareholder $i(i \in I)$ is $K_{i}$, and assume the potential expropriation by majority shareholders constitutes the benefit loss of minority shareholders, and assume the opportunity cost borne by minority shareholders or the opportunity benefit received by majority shareholders due to the expropriation is $L_{i}$. Because of the existence of agency problems, the necessary opportunity cost can guarantee the minority shareholders' basic demand on corporate governance and maintain the basic benefit of $u_{i}$, and on this basis the probability of the minority shareholders' successful participation in corporate governance is $\theta_{i}\left(0 \leq \theta_{i} \leq 1\right)$. Through the agency of majority shareholders, minority shareholders participate in some projects or operational decision-making, and within this limit, the condition to allow the majority shareholders' expropriation is that the result of the agent benefit minus the expected cost is greater than or equal to zero.

Namely

$$
\left(1+u_{i}\right)\left(K_{i}+L_{i}\right)-\theta_{i} L_{i} \geq 0 .
$$

This paper takes the sanction by the relevant departments for the majority shareholders' expropriation as external legal environment change events, so whether the return of the listed company shows significant difference during the window before and after the listed company has been sanctioned by the relevant departments for the majority shareholders' expropriation will be the judgment whether the sanction have any obvious effect on the listed company and stock market. No doubt, the sanction on the listed company for the majority shareholders' expropriation will increase the $\theta_{i}$ to reduce the expected cost and risk of the agency, thus to some extent reducing the majority shareholders' expropriation, which is regarded as a typical "good" signal for the listed company in the capital market based on the general theory of investor protection and expects to exert a positive impact on the profit of the listed company. In addition, the identified expropriation will also generate additional punishment cost, lawsuit fees, etc. Therefore, the listed company reduces the possibility of expropriation by majority shareholders at the expense of the ascension of the exogenous agency cost.

b) The Minimum Agency Cost for Minority Shareholders under Expropriation Behavior

As mentioned above, the agency dilemma among shareholders of the listed company can be partly cushioned through the management. Even majority shareholders and the management allied together, they have conflict of interests with each other because the management has its own interests. Therefore, according to the experience and behavior logic and with the intervention of the management as agent, the expropriation by majority shareholders will be reduced for the high expropriation cost, thus reducing the agency cost of minority shareholders.

Assume the management of the listed company is the risk-neutral managerial executives, and their opportunity cost for the agency of majority shareholders is $b_{i}$, namely, the benefits can be obtained by majority shareholders through the management; Their agency cost for the agency of minority shareholders is $S_{i}$ times of the expected benefits.

The condition for the management to provide agency for minority shareholders to participate in corporate governance is that the expected benefits is not less than the benefits they may receive when they provide agency for majority shareholders.

Namely

$$
\left(1+u_{i}\right)\left(K_{i}+L_{i}\right)-S_{i} L_{i} \geq\left(1-b_{i}\right) L_{i} .
$$

Seen from the above formula (2), the reason why the agency cost of majority shareholders is lower than that of minority shareholders is that majority shareholders have a big-sum equity capital with a low implementing cost of the agency behavior. With other parameters remain constant, the higher the agency cost for minority shareholders is, the more majority shareholders obtain from their expropriation. Investigating into the event that minority shareholders are passive in the principal-agent relationship and expropriated by majority shareholders, we assume that the risk-neutral management will not tend to bias toward minority shareholders or majority shareholders in the process of actually running the company, and not produce tort boundary of malicious proxy. So, the more strict the exogenous variables of the legal environment is, the bigger the opportunity cost of violat- 
ing the laws and regulations represented by $b_{i}$ is, thus further becoming the institutional constraints for the majority shareholders' expropriation.

According to the theoretical model based on the aforesaid tort mechanism and investor protection, the punishment announcement on the listed company's violation of laws and regulations should be good news in stock market and the reaction from the market should be positive. The punishment announcement demonstrates the strict attitude of the securities regulator toward the listed company's violation of laws and regulation, and exerts a deterrent to any violation attempts in the market. Meanwhile the punishment announcement also illustrates the increasing possibility that the violation activities by the listed company insiders are investigated and punished, thus constituting an external constraint mechanism for the listed company insiders, inhibiting and reducing the violations by the listed company insiders, and strengthen the protection of investors (especial minority shareholders) and enhance the value of the company.

\section{The Empirical Study}

By applying the event study method and taking the sanction as the legal environment change events for the listed company, this section attempts to discuss the stock market's reaction to the punishment announcement for the violation of laws and regulations by the listed company, whether the rights and interests of shareholders are affected by the violation and the ensuing sanctions. In this paper, the violation events mainly include following three types, the related transactions, insider trading and the shareholders' fund embezzlement. The specific data comes from the special database on the violation of listed company by the CSMAR and the special research database by RESSET Database.

\subsection{Indicator Setting and Data Selection}

According to the event study method, the first step is to determine the event window after the selected event has happened and the estimated window as a comparison. This paper assumes the time $t$, the date of the punishment announcement, as the event day, and defines the event window as $t-100$ and $t-5$, and the estimated window as $t+1$ and $t+5$. This paper uses the fixed-expected-income statistical model to calculate the normal expected return within the event window period, and calculates the abnormal return Ari and the cumulative abnormal return $C A R_{i}$ within the event window period. In this paper, the daily return is the daily one after dividend-distribution, and the data comes from the RESSET database.

The period in which the punishment announcement have been made public for the shareholders' expropriation ranges from January 4, 2011 to June 30, 2015, and a total of 3122 company-time have been screened out as the research object, namely, taking the external punishment measures as the event that a listed company's legal environment has changed. Further, among all these companies, 1044 listed company-time have been sanctioned for the shareholders' expropriation. In order to more intuitively investigate whether the shareholders' interests are influenced by the legal sanction for the shareholders' expropriation, this paper excludes the multiple penalties caused by multiple violations. The remaining 576 listed companies have constituted 576 violation-punishment events for the shareholders' expropriation, and this paper has randomly selected as much as $10 \%$ of the violation-punishment events as sampling statistics.

\subsection{The Model and the Formula}

Using the fixed-income method as measurement standard, this paper selects the average value of the return as the normal return or the average return during the window period, and defines the difference between the average value and the actual value as the measurement indicator of the abnormal return $A R_{i}$ caused by the market response to the legal environment change after the punishment announcement of the listed company. In addition, the cumulative sum of the $A R_{i}$ during the predicted window period is the cumulative abnormal return $C A R_{i}$. The formula is as follows:

$$
\begin{gathered}
A R_{i t}=R_{i t}-E\left(\sum_{i=1}^{n} \sum_{t=t-100}^{t-5} R_{i t}\right) \\
E\left(\sum_{i=1}^{n} \sum_{t=t-100}^{t-5} R_{i t}\right)=\frac{1}{96} \sum_{i=1}^{n} \sum_{t=t-100}^{t-5} R_{i t}
\end{gathered}
$$




$$
C A R_{i t}=\sum_{t=0}^{t=t+5} \sum_{i=1}^{n} A R_{i t} .
$$

In order to avoid the big fluctuation of the abnormal return brought by the particularity of one single stock, this paper takes the average value of the sample as a reference for the abnormal return.

\subsection{The Result of the Data Experiment}

Table 1 gives a descriptive statistics of the daily abnormal return during the following five trading days after the date of the punishment announcement. On the trading day $t$, the abnormal return is negative, while during the following two days, the abnormal return is positive. Intuitively, the punishment announcement exerts negative effect on the shareholders' earnings (share price), and the impact is mainly manifested on the day of the punishment announcement and the first day after the punishment announcement. Starting from the second day, the negative effect is eliminated and the share price rebounds somehow.

Table 2 shows the change of the related parameters of the cumulative abnormal return. During the $1^{\text {st }}$ three days the cumulative abnormal return is negative: the abnormal return reaches the lowest on the day of $t+1$, and begins to recover on the day of $t+2$, but still stays below zero. As you can see, during the event window period, the punishment brings comparative large loss to the company's shareholders.

Table 3 shows the test value and P-value of the average value of the abnormal daily return and the cumulative abnormal daily return, and marks the significant level. The test of the median value further illustrates that the punishment announcement for listed companies' violation of laws and regulations exerts a negative effect on the value and the return of the stock. The negative influence mainly focuses on the fifth day of the $t+5$ from the perspective of significance, and since then, it adjusts and rebounds somewhat, but the accumulative influence still remain negative. Although the cumulative value doesn't pass the test of significance, the empirical result fully shows that the punishment for the expropriation by the shareholders of the listed company brought comparative loss of market value to other shareholders, and doesn't positively increase the market value as theoretical model explores.

The selected sanction events are the violation events of the shareholders' expropriation; therefore, the expropriation by majority shareholders exerts direct negative effect on the benefits of minority shareholders. In a relatively short period of time the negative effect will transmit a punitive "good" signal as the investor protection theory proposes, and rational investors will expect the punitive measures to strengthen the management of the listed company, i.e. the improved legal environment will help strengthen the corporation's operation and management and reduce the effect of the majority shareholders' expropriation of other shareholders. However, the

Table 1. The abnormal daily return during window period from perspective of event study.

\begin{tabular}{ccccccc}
\hline$A R_{i}$ & $t-0$ & $t+1$ & $t+2$ & $t+3$ & $t+4$ & 0.004189 \\
mean & -0.00307 & -0.00126 & 0.003957 & 0.003239 & 0 & 0.008 \\
median & 0.001812 & 0 & 0 & 0 & 0.033573 \\
std & 0.037785 & 0.030075 & 0.032462 & 0.039136 & -0.0849 \\
$\min$ & -0.10716 & -0.0895 & -0.0963 & -0.0786 & 0.1645 \\
$\max$ & 0.07671 & 0.082 & 0.0988 & 0.035 & 0.099 \\
\hline
\end{tabular}

Table 2. The cumulative abnormal daily return during window period from perspective of event study.

\begin{tabular}{ccccccc}
\hline CAR & $t-0$ & $t+1$ & $t+2$ & $t+3$ & $t+4$ & -5 \\
mean & -0.00307 & -0.00432 & -0.00037 & 0.002873 & 0.007062 \\
median & -0.00439 & -0.00636 & -0.00271 & 0.001844 & 0.006795 & -0.00096 \\
std & -0.00447 & -0.00647 & -0.00276 & 0.001877 & 0.006917 \\
min & -0.00422 & -0.00588 & -0.00202 & 0.002169 & 0.00694 \\
$\max$ & -0.0043 & -0.00599 & -0.00205 & 0.002208 & -0.00129 \\
\hline
\end{tabular}


Table 3. The significance of the cumulative abnormal daily return and cumulative abnormal daily return during window period from the perspective of event study.

\begin{tabular}{ccccccc}
\hline$A R_{i}$ & $t-0$ & $t+1$ & $t+2$ & $t+3$ & $t+4$ & $t+5$ \\
\hline mean & -0.00307 & -0.00126 & 0.003957 & 0.003239 & 0.004189 & -0.008 \\
$\mathrm{t}$ & -0.6073 & -0.3128 & 0.9122 & 0.6194 & 0.9338 & -1.4798 \\
$\mathrm{P}$ & 0.2731 & 0.3778 & 0.1828 & 0.2691 & 0.1772 & $0.0723^{*}$ \\
\hline$C A R_{i}$ & $t-0$ & $t+1$ & $t+2$ & $t+3$ & $t+4$ & $t+5$ \\
\hline mean & -0.00307 & -0.00432 & -0.00037 & 0.002873 & 0.007062 & -0.00093 \\
$\mathrm{t}$ & -0.6073 & -0.5716 & -0.0388 & 0.3669 & 1.1713 & -0.1584 \\
$\mathrm{p}$ & 0.2731 & 0.285 & 0.4846 & 0.3576 & 0.1233 & 0.4374 \\
\hline
\end{tabular}

positive and negative effects shown by the empirical result almost all don't pass the significance test, which rightly explains that the legal system demonstrated by the punitive measures has limited effectiveness to standardize the internal governance of listed companies, and further illustrates the significance of the improvement of the legal environment to enhance the management and operation of listed companies. In other words, there is a room to further improve the legal environment, enhance the standardized operation of the corporation and reduce the majority shareholders' expropriation of minority shareholders.

\section{Policies and Suggestions}

With the completion of the split-share structure reform and the construction of modern enterprise system, the market environment of "the same share with the same right" and all-round circulation of stock has been formed. Following the change of the market environment, policy background, laws and regulations, majority shareholders' self-interest orientation, etc., the change of the majority shareholders' expropriation is an objective phenomenon and trend. After the reform of the split-share structure, majority shareholders diversify their repression and expropriation of minority shareholders. The false information disclosure, market manipulation, insider trading, malicious restructuring, mergers and acquisitions bring great loss to minority shareholders, continuously challenging the protection of minority shareholders who are in a disadvantaged position. The research background of the post-split-share structure reform necessitates the normalization of the majority shareholders' expropriation, and lays a foundation for the regularization of the expropriation pattern. Because the passive state of minority shareholders in principal-agent relationship is inevitable and normal, the majority shareholders' expropriation of minority shareholders is a rational choice. Based on them, the following preventive measures or governance strategy are rational and practical.

1) Optimizing Equity Structure and Perfecting Corporate Governance

During the split-share structure period, the low proportion of outstanding shares distorts the function of the securities market, and the share price cannot fully reflect the operating performance of the listed company, thus the securities market cannot give full play to its function of optimizing the allocation of resources. In their study of the ownership structure, scholars usually want to distinguish between the endogenous and exogenous nature of the equity structure. In fact, the formation of the equity structure has its legal, institutional and historical driving factors, and the view of the exogenous equity structure is already relatively mature. Combined with the model itself, the exogenous nature of $S_{i}$ contains the equity structure. Based on the capital amount and equity structure, the expectancy on utility among the shareholders' conflicts of interest is generated from the trade-off between costs and benefits.

With the rational optimization of equity structure, the size of the $S_{i}$ will change in a periodical or gradient way. Before the split-share structure reform, the state-owned shares and state-owned legal person shares account for a comparatively big proportion and cannot be circulated in the secondary market, therefore it is difficult to ultimately establish a corporate governance structure in the true sense, and the $S_{i}$ will be expanded infinitely for minority shareholders have no choice. Late in the split-share structure reform, measures shall be taken to safely continue the reduction of state-owned shares, gradually reducing the proportion of state-owned equity, thus reducing the controlling shareholders' expropriation motivation to a certain extent. 
There are two ways to reduce the proportion of the state-owned shares: one way is the increase of nonstate-owned shares. When increasing its capital, the listed company increases the non-state-owned shares, thus diluting the original state-owned shares. The other one is the change of state-owned shares. The listed company changes its state-owned shares for non-state-owned shares and the remaining state-owned shares take a holding or participating position. In this way, the structure of corporate governance can be reconstructed, solving the absence problem of state-owned property rights to a certain extent. The reduction of the state-owned shares will also cause the change of the corporate governance structure, and the shareholders' supervision enthusiasm and efficiency will be improved, thus realizing the diversification of investors and improving equity structure. The balance mechanism of multiple majority shareholders means the sharing of the control by several majority shareholders, forming the institutional arrangement of checks, balance and supervision among majority shareholders and regulating the majority shareholders' expropriation of minority shareholders.

2) Actively Developing Institutional Investors and Protecting Small and Medium-Sized Investors

Institutional investors are the $3^{\text {rd }}$-party force falling between the internal shareholders and the external small and medium-sized investors. Comparing with individual investors, institutional investors have the advantages of resource, information, professional expertise and ability, and can hold an advantage over the management and majority shareholders in the checks and balances of the listed company. Although minority shareholders are the main investment bodies in the securities market, they can only play a small part in the corporate governance of the listed company due to the information asymmetry.

The corporate governance practices in the developed countries show that with the their continuous growth, institutional investors, by using the voting mechanism, can actively participate in corporate governance and even influence the major decision-making of the listed company, freeing from the expropriation by majority shareholders and the managements. Meanwhile, as the backbone of a stable securities market, institutional investors can help small and medium-sized investors to overcome their short-sighted behavior and cultivate long-term investment philosophy, thus inhibiting the "flock effect" in securities market. Therefore, the cultivation of diversified investment bodies and guiding institutional investors into corporate governance can improve the efficiency of the supervision of and check on controlling shareholders and make up for the absence or shortage of supervision by minority shareholders.

China should gradually solve the dominance of the state-owned shares and the low proportion of circulating shares to protect small and medium-sized investors. During the late period of the split-share structure reform there is no lack of the phenomenon that institutional investors expropriate small and medium-sized investors. Therefore, the active regulatory measures must be taken to supervise and constrain the complicity of institutional investors and majority shareholders to prevent institutional investors from seeking illegal profits with its information advantage.

3) Strengthening Market Supervision Mechanism and External Legal Environment

Regarding from the regulatory way, China's present securities regulation system is one kind of all-around regulation. On one hand, this kind of regulatory system leads to the dispersion of the regulatory power without prominent regulatory focus; while on the other hand, the excessive regulation in some aspects not only creates room for "rent-seeking" but also increases the transaction costs of all parties concerned. In terms of perfecting the information disclosure system, all real information concerning every links and parts of the issuance and circulation shall be disclosed for small and medium-sized investors as reference in their investment-decision. If the disclosure of information is not timely, complete or true, it is likely to mislead the small and medium-sized investors to make wrong decisions, causing damage to them accordingly. Therefore, it is necessary to establish a perfect information disclosure system, standardize the information disclosure of listed companies, thus protecting small and medium-sized investors and their confidence in securities market, and guiding the social resources flow to those departments with high efficiency.

4) Perfecting Legal System to Protect Minority Shareholders

The perfect legal system is a fundamental guaranty of the legal rights and interests of investors. The convenience of the exercise of rights and the convenience of litigation are two important indexes measuring the protection of minority shareholders. As one kind of pre-prevention mechanism, the convenience of the exercise of rights helps minority shareholders give a timely response to the company's activities that may infringe on their rights and interests by voting with their feet or voting with hand. As one ex post facto mechanism, the convenience of litigation means that minority shareholders, after being expropriated, can obtain recourse against the infringer to protect themselves through the civil litigation process with relatively low cost, less time and high 
probability of winning the case.

5) Strengthening Investor Education and Safeguarding Legitimate Rights and Interests

While the legal system and government regulation are the external ways to protect minority shareholders, the self protection of minority shareholders is an important factor to maintain the sustainability of the external protection mechanism. Minority shareholders cannot excessively rely on the protection of the government and the laws and regulations, and lose the ability of self-protection. On the one hand, minority shareholders must make good use of the investor education platform, fully understand their legitimate rights and interests, protect their rights and interests by applying legal tools, and enhance their right-protection awareness. On the other hand, due to the incomplete legal system and the lagging-behind government regulatory information, the hidden violation or expropriation may not be discovered and punished in time. Therefore, minority shareholders, aware of their legitimate rights and interests infringed on, should resort to the regulatory authority or the investors-protection association as soon as possible, to prevent further loss.

\section{References}

[1] La Porta, R., Lopez-de-Silanes, F., Shleifer, A. and Vishny, R.W. (2002) Investor Protection and Corporate Valuation. Journal of Finance, 57, 1147-1170. http://dx.doi.org/10.1111/1540-6261.00457

[2] Claessens, S., Djankov, S. and Lang, L.H.P. (2000) The Separation of Shareholdership and Control in East Asian Corporations. Journal of Financial Economics, 58, 81-112. http://dx.doi.org/10.1016/S0304-405X(00)00067-2

[3] Faccio, M. and Lang, L.H.P. (2002) The Ultimate Shareholdership of Western European Corporations. Journal of Financial Economics, 65, 365-395. http://dx.doi.org/10.1016/S0304-405X(02)00146-0

[4] Feng, G.F. (2004) Double Principal-Agent Theory: Another Analysis Framework of Listed Companies’ Governance- The New Ideas to further Improve the Corporate Governance of Listed Company. Economic Research Journal, No. 12, 16-25.

\section{Submit or recommend next manuscript to SCIRP and we will provide best service for you:}

Accepting pre-submission inquiries through Email, Facebook, LinkedIn, Twitter, etc.

A wide selection of journals (inclusive of 9 subjects, more than 200 journals)

Providing 24-hour high-quality service

User-friendly online submission system

Fair and swift peer-review system

Efficient typesetting and proofreading procedure

Display of the result of downloads and visits, as well as the number of cited articles

Maximum dissemination of your research work

Submit your manuscript at: http://papersubmission.scirp.org/ 